\title{
An Analysis Minimal Exchange Structures and GeneralExchange Structure in English Classroom Interaction Found in Youtube
}

\author{
Regina Marintan Silalahi, reginasilalahi0126@gmail.com, English Teaching Learning \\ Program, Education Faculty, Nommensen HKBP University, Medan, Indonesia
}

\section{Kammer Tuahman Sipayung, kammertuahmansipayung@gmail.com, English Teaching Learning Program, Education Faculty, Nommensen HKBP University, Medan, Indonesia}

\begin{abstract}
This research reported study about analysis minimal exchange structures and general exchange structure in English classroom interaction found in you tube, (from mujikuy channel : asking and giving information about berbasis ganre in $\mathrm{x}$ class). This study direct to analysis the element of minimal exchange structures and general exchanges structures in English classroom interaction find in you tube. The data is the clauses obtained from conversation among teacher and students of $\mathrm{X}$ grade during English classroom learning process that find in you tube from (Mujikuy channel : asking and giving information about berbasis ganre in $\mathrm{x}$ class). This study uses theory of Halliday (1994) by qualitative descriptive method. The result shows that there are three (3) types of act as the element of exchange structures: Initiating, Responding, and Following-Up (I-R-F). Minimal exchange structure consists of: Initiating-Responding (I-R) or Initiating-Responding-Following Up (I-R-F). General structure of exchange in classroom situation consists of: greeting, giving order, giving information, asking question, and closing. In the learning process, things do not always go well. When the learning process students sometimes do not respond to conversations or instructions given by the teacher. Therefore teachers must take initiatives such as providing information, asking questions, and giving instructions. So that the learning process becomes more efficient. This study shows that the teacher has the authority to regulate learning activities

Keywords: analysis, exchange structure, classroom interaction.
\end{abstract}

\section{INTRODUCTION}

Language is used by human beings to communicate among one another. Language and human cannot be separated each other. Language as a communication mean is necessary to be mastered. Without language, it is impossible for human to communicate and interact with others well. Everyone makes daily activities using language. These activities include talking with friend, listening to teachers, reading assigment, surfing the internet, etc. Without language, none of these activities would be possible. Language allows you to speak, read, write, listen to others, and even talk to yourself or to think.

By language human can express their feeling and thinking. With language people can share their ideas. It is hard to imagine if people do not have language in their communication. Using language in a communication is aimed to know what messege and what information that will be delivered to other people.

English is rapidly gaining status as a global language. This is true because the language is not only used in English-speaking countries but also in other countries where businesses flourish through negotiations delivered in English. In this case, English becomes the people's second or foreign language. The communication in English occurs in many contexts, like an advertisement, education and business, and the like. (Sipayung, 2019:95).

It is important for us to study. As we know language is needded to communicate in a society. The social interaction and communication of ideas or massage can be delivered by

230 | IJET| Volume. 10, Issue 2. December 2021

Copyright 2021 Regina Marintan Silalahi, and Kammer Tuahman Sipayung are licensed under Creative Commons Atrribution-ShareAlike 4.0 International License. 
using language. Language has relationship with society because it is used for communicate with others. Knowing the way to use language in society so that we can use language appropriately and communication will run well. One of the ways to know language use in society is learning sociolinguistic. Sociolinguistic is study of relationship between language and society.

language is composed in a system and structure used by speakers to make conversation good. and in each conversation process, each spokesperson must pay attention and listen to the topic of conversation and situation. A speaker will generate effective communication when the speaker knows the system. The process itself involves interactions that occur between the speaker (addresser) and the listener (addresser).

when there is a process of conversation with each other, they provide an exchange of information. very useful information for every human being. because with information we can find out about what is happening in the world. This also occurs when the teaching and learning process is in progress, where the teacher provides information and asks questions to students. when the teaching and learning process the teacher often asks questions to students, it is because the teacher wants to know how much knowledge the students have and the teacher wants to test how capable the students are when conveying information.

In the conversation process, there is a process of exchanging information between the speaker and the listener, the use of exchange structures in the process of transferring information becomes important in the teaching and learning process. teachers can improve the way students convey information, transfer their knowledge and increase the opportunity to master the language. The structure of the interaction is an important aspect of language use that speakers and listeners must pay attention to when transferring information.

Functional grammar is an instrument in discourse analysis. Saragih (2004:1) state the discourse is a meaning the realized in the text. Although, there are many linguist who give different definition of discourse and text, the researcher use the term discourse as the same perspective. Since discourse is the realization of meaning in the text, we can use it to anylisi exchange structures (move), speech function, and mood (Saragih, 2004 : 14).

Discourse analysis help us understand use how real language, as apposed to studying artificially created sentences. It is therefore of immediate interest to language teachers because we need to consider how people use language when we design teaching materials, or when we angage learners in exercises and activities aimed at making them proicient users of their target language, or when we evalua te a piece of commercially published material before decinding to use ( Yu. W, $2009: 1$ )

Based on the description above, the writer will analyze the language aspects in the view of analyzing systematic functional linguistic discourse analysis. This study will focus on exchange structures in English classroom interaction on YouTube.

Halliday (1994: 608) system functional linguistic (SFL) is a centered on a notion of language function. It is concerned with the realization between language and context, interpersonal meaning in the text. SFL is very useful in analysis the language grammar which is focused on the relation between text and social context which express a meaning in a system of communication. Language is used by human being to create their needs and to make meaning for the social life.

According to SFL (1994: 608) human being use language in order to fulfil three function known as metafunction namely : to present, to exchange and to organize experience. Technically metafunction are term as identional, interpersonal, and textual function.

According to Sinclair and Coulthand in Rafjasani (2018:10). exchange structures is sequence of communication that can be used to analyze the types of conversations. They develop a model exchange consisting of three parts : a questions, an answer, and a comment. The sequence of parts, each labelled as move, consists of initation (I) from the speaker, response (R) which is the speaker's comment on hearer, and follow up (F) which is the 
speaker's comment on hearer's answer. These moves are abbreviated to I-R-F and general exchange structures in english classroom interaction consists of : greeting, followed any kinds of functions such as, giving information, giving order, asking question, and closing.

Based on these explanations, the authors chose to conduct a discourse focus analysis on exchange structures in English class interactions. The researcher will found the patterns of minimal exchange structures and general exchange structure in English Classroom interaction in youtube (from mujikuy channel : asking and giving information about berbasis ganre in $\mathrm{x}$ class). In this research, after collecting data, the writer will analyze the data by performing descriptive analysis Ary, Lucy, and Chris (2010 : 32). The techniques that will be used to analyze data are: recordings, observation, transcribing, and analyzing. To Analyze the data, the writer will follow the following the steps:

1. Find the clause

2. Find the minimal and general Exchange Structures

3. Make the verification 
Figure 2.2 Elements of Exchange Structure (Halliday, 1994)

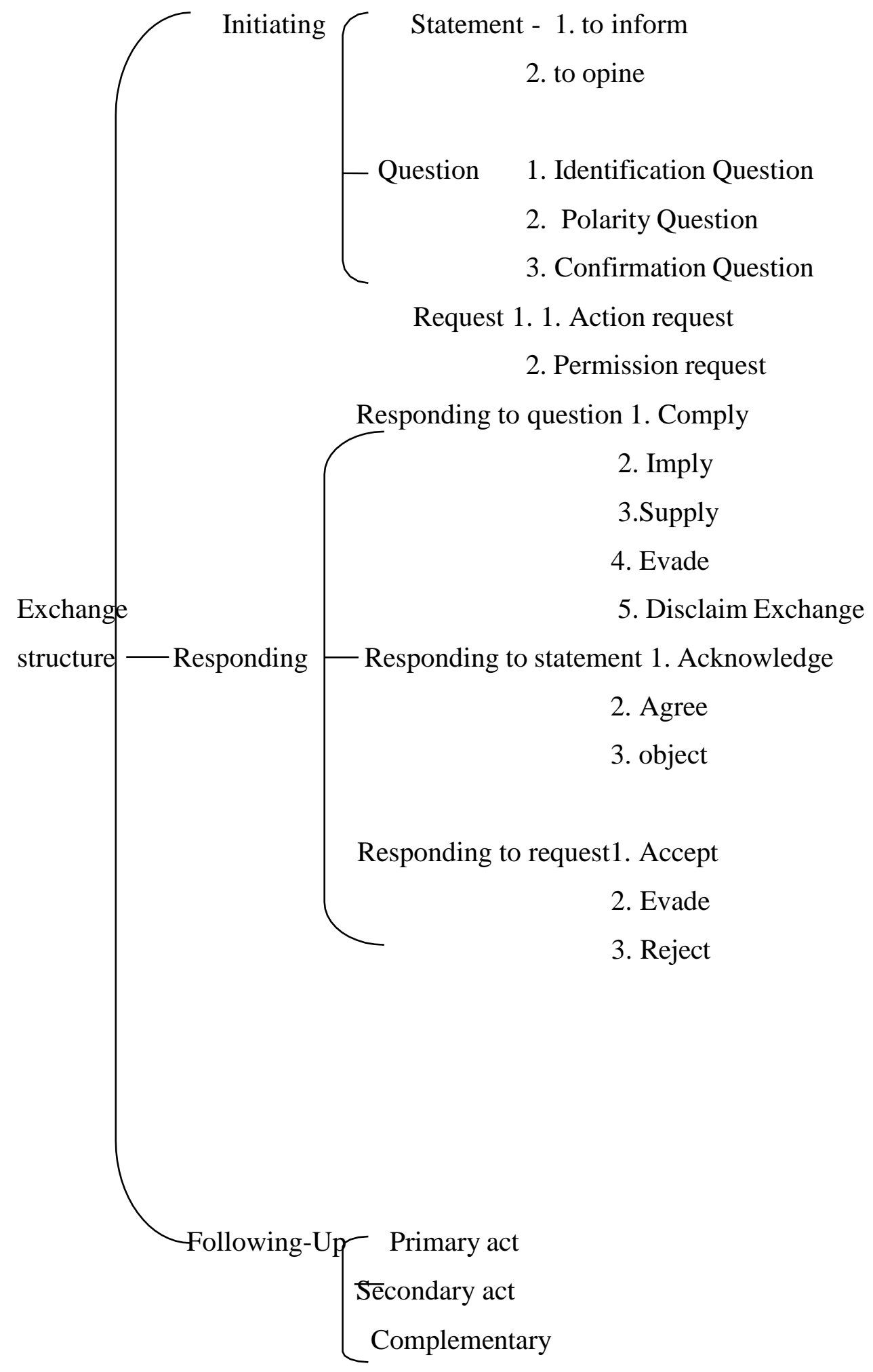

\section{METHOD}

The method of this research will be conducted by using descriptive qualitative method. Descriptive research study is design to describe condition, event or situation. As, Creswell (2014 : 32) Qualitative researcher an approach for exploring and understanding the 
meaning individuals or groups ascribe to a social or human problem. The research will use descriptive qualitative to describe the conversation of teacher and students that found in 
youtube. The research describe minimal Exchange Structure and general Exchange Structures in English classroom interaction under a natural in the class by vidio-recording. So, the subjects of the research are teacher and students in English classroom interaction. The data of the study will focus on the teaching and learning process by analyzing the minimal exchange structures and general exchange structure found in English Classroom interaction in youtube from mujikuy channel : asking and giving information about berbasis gaanre in $\mathrm{X}$ class.

\section{RESULT}

The data of this study will be clauses with consist uttered by teacher and students in English classroom interaction found in youtube from mujikuy channel : asking and giving information about berbasis gaanre in X class. Then, teacher in English classroom as the sources of data. The data was analyzed by using descriptive qualitative data. The qualitative data of the study was taken from teacher and student's conversation during learning process in youtube. This study was conducted at ten grade of senior high school.

Data 4.1 English Classroom Interaction

\begin{tabular}{|c|c|c|}
\hline NO & English Classroom Interaction & Clause \\
\hline 1 & $\begin{aligned} \text { Teacher : you are so happy and fresh } \\
\text { today, I'm glad too see this. It } \\
\text { mean you are all ready for } \\
\text { English lesson. right? }\end{aligned}$ & $\begin{array}{l}\text { 1. you are so happy and fresh today, } \\
\text { 2. I'm glad to see this } \\
\text { 3. It mean you are all ready for } \\
\text { English lesson. right }\end{array}$ \\
\hline 2. & Teacher : chairman, please lead the pray. & 4. chairman, please lead the pray. \\
\hline 3. & $\begin{array}{c}\text { Student } 2 \text { (Tina): they are outside ma'am } \\
\text { they came late. }\end{array}$ & 5. they came late. \\
\hline 4. & $\begin{array}{l}\text { Teacher: that's good, it means you like } \\
\text { reading right? }\end{array}$ & $\begin{array}{l}\text { 6. that's good } \\
\text { 7. Means you like reading right? }\end{array}$ \\
\hline 5. & $\begin{array}{l}\text { Student } 7 \text { (sari): } \text { I'm agree with Adam } \\
\text { opinion ma'am. In } \\
\text { daily live we usually } \\
\text { tell our experience to } \\
\text { others. }\end{array}$ & $\begin{array}{l}\text { 8.I'm agree } \\
\text { 9. with Adam opinion ma'am. }\end{array}$ \\
\hline 5. & $\begin{array}{c}\text { Teacher :ok well class. I'm going to show } \\
\text { you a vidio. And please watch } \\
\text { the conversation and then } \\
\text { repeat it and you have to do } \\
\text { the task in the workheet given. }\end{array}$ & 1O. I' $m$ going to show you a vidio. \\
\hline 6. & $\begin{array}{l}\text { Teacher: sure, what do you want to ask } \\
\text { tina? }\end{array}$ & 11. sure, what $d o$ you want to ask tina? \\
\hline 7. & $\begin{aligned} \text { Student } 18: & \text { it is stated here, that we use } \\
& \text { present perfect tense when } \\
& \text { we are considering } \\
& \text { something that started in the }\end{aligned}$ & $\begin{array}{l}\text { 12. it is stated here, that we use present } \\
\text { perfect tense } \\
\text { 13. when we are considering something } \\
\text { that started in the past and connect to the }\end{array}$ \\
\hline
\end{tabular}




\begin{tabular}{|c|c|c|}
\hline & $\begin{array}{l}\text { past and connect to the } \\
\text { present }\end{array}$ & present \\
\hline 8. & $\begin{array}{l}\text { Student 19: oh I have been here for quite } \\
\text { a while }\end{array}$ & 14. I have been here \\
\hline 9. & $\begin{array}{l}\text { Teacher : ok class, after you understand } \\
\text { the simple past and present } \\
\text { perpect. I'm going to give you } \\
\text { another text. }\end{array}$ & $\begin{array}{l}\text { 15. after you understand the simple past } \\
\text { and present perpect } \\
\text { 16. I' } m \text { going to give you another text. }\end{array}$ \\
\hline 10. & $\begin{aligned} \text { Student } 22: & \text { I agree with you, next host } \\
& \text { elaborates the question. } \\
& \text { Again } \quad \text { RidwanKamil } \\
& \text { responds it. }\end{aligned}$ & $\begin{array}{l}\text { 17. I agree with you } \\
\text { 18. next host elaborates the question. }\end{array}$ \\
\hline 11. & $\begin{array}{c}\text { Teacher: I am happy to hear that, don't } \\
\text { worry, we still have another } \\
\text { meeting to discuss about it . }\end{array}$ & $\begin{array}{l}\text { 19. I am happy to hear } \\
\text { 20. we still have another meeting }\end{array}$ \\
\hline 12. & $\begin{array}{l}\text { Teacher : now let us conclude what you } \\
\text { have learned today. }\end{array}$ & $\begin{array}{l}\text { 21. now let usconclude } \\
\text { 22. what you have learned today. }\end{array}$ \\
\hline 13. & $\begin{aligned} \text { Teacher : we have also learned, how we } \\
\text { ask and give information about } \\
\text { experiences or past events } \\
\text { using past simple or present } \\
\text { perpect. If we give } \\
\text { information about an event } \\
\text { which finished at a specific } \\
\text { time in the past, we use past } \\
\text { simple. When we want to } \\
\text { stress the importance of a past } \\
\text { event in the present, we use } \\
\text { present perpect. }\end{aligned}$ & $\begin{array}{l}\text { 23. we have also learned, } \\
\text { 24. how we ask and give information about } \\
\text { experiences or past events using past } \\
\text { simple or present perpect. } \\
\text { 25. If we give information about an event } \\
\text { which finished at a specific time in the past } \\
\text { 26. we use past simple. } \\
\text { 27. When we want to stress the importance } \\
\text { of a past event in the present, } \\
\text { 28. We use present perpect. }\end{array}$ \\
\hline 14. & $\begin{array}{l}\text { Teacher: thank you, you give a good } \\
\begin{array}{l}\text { conclusion Let's give } \\
\text { applause. }\end{array}\end{array}$ & $\begin{array}{l}\text { 29. thank you, } \\
\text { 30. you give a good conclusion }\end{array}$ \\
\hline
\end{tabular}

Nb : Bold : Subject

: Italic Bold : Verb

Clauses : 30

236 | IJET| Volume. 10, Issue 2. December 2021

Copyright 2021 Regina Marintan Silalahi, and Kammer Tuahman Sipayung are licensed under Creative Commons Atrribution-ShareAlike 4.0 International License. 


\section{a. Minimal Exchange Structures and General Exchange Structure in English} Classroom Interaction

\begin{tabular}{|c|c|c|c|c|}
\hline \multirow[t]{2}{*}{ NO } & \multirow{2}{*}{$\begin{array}{l}\text { English Classroom } \\
\text { Interaction }\end{array}$} & \multirow[t]{2}{*}{ Clause } & \multicolumn{2}{|l|}{ Exchange structures } \\
\hline & & & Minimal & General \\
\hline \multirow[t]{3}{*}{1.} & \multirow{3}{*}{$\begin{array}{l}\text { Teacher : you are so } \\
\text { happy and fresh } \\
\text { today, I'm glad too } \\
\text { see this. It mean } \\
\text { you are all ready for } \\
\text { English lesson. } \\
\text { right? }\end{array}$} & $\begin{array}{l}\text { 1. you are so happy } \\
\text { and fresh today } \\
\text { 2. I'm glad to see this }\end{array}$ & $\begin{array}{l}\text { Initiating }>\text { statement }>\text { to } \\
\text { opine } \\
\text { Initiating }>\text { statement }>\text { to }\end{array}$ & $\begin{array}{l}\text { Greetings } \\
\text { Giving }\end{array}$ \\
\hline & & & opine & information \\
\hline & & $\begin{array}{l}\text { 3. It mean you are } \\
\text { all ready for English }\end{array}$ & $\begin{array}{l}\text { Initiating }>\text { question }> \\
\text { polarity questin }\end{array}$ & $\begin{array}{l}\text { Asking } \\
\text { question }\end{array}$ \\
\hline 2. & $\begin{array}{l}\text { Teacher : chairman, } \\
\text { please lead the pray. }\end{array}$ & $\begin{array}{l}\text { 4. chairman, please } \\
\text { lead the pray. }\end{array}$ & $\begin{array}{l}\text { Initiating }>\text { request }> \\
\text { action request }\end{array}$ & $\begin{array}{l}\text { Giving } \\
\text { order }\end{array}$ \\
\hline 3. & $\begin{array}{l}\text { Student } 2 \text { (Tina): } \\
\text { they are outside } \\
\text { ma'am they came } \\
\text { late. }\end{array}$ & 5. they came late & $\begin{array}{l}\text { Responding > responding } \\
\text { to statement }>\text { acknowledge }\end{array}$ & $\begin{array}{l}\text { Giving } \\
\text { information }\end{array}$ \\
\hline \multirow[t]{2}{*}{4.} & \multirow{2}{*}{$\begin{array}{l}\text { Teacher: that's } \\
\text { good, it means you } \\
\text { like reading right? }\end{array}$} & 6. that's good & $\begin{array}{l}\text { Responding }>\text { responding } \\
\text { to statement }>\text { agree }\end{array}$ & $\begin{array}{l}\text { Giving } \\
\text { information }\end{array}$ \\
\hline & & $\begin{array}{l}\text { 7. means you like } \\
\text { reading right? }\end{array}$ & $\begin{array}{l}\text { Initiating > question }> \\
\text { confirmation question }\end{array}$ & $\begin{array}{l}\text { Asking } \\
\text { question }\end{array}$ \\
\hline \multirow[t]{2}{*}{5.} & \multirow{2}{*}{$\begin{array}{l}\text { Student } 7 \text { (sari) : i'm } \\
\text { agree with adam } \\
\text { opinion ma'am. In } \\
\text { daily live we tell ou } \\
\text { r experience to } \\
\text { others. }\end{array}$} & 8.I'm agree & $\begin{array}{l}\text { Responding > responding } \\
\text { to statement }>\text { agree }\end{array}$ & $\begin{array}{l}\text { Giving } \\
\text { information }\end{array}$ \\
\hline & & $\begin{array}{l}\text { 9. with adam opinion } \\
\text { ma'am. }\end{array}$ & $\begin{array}{l}\text { Responding > responding } \\
\text { to statement > agree }\end{array}$ & $\begin{array}{l}\text { Giving } \\
\text { information }\end{array}$ \\
\hline 6. & $\begin{array}{l}\text { Teacher :ok well } \\
\text { class. I'm going to } \\
\text { show you a vidio. } \\
\text { And please watch } \\
\text { the conversation } \\
\text { and then repeat it } \\
\text { and you have to do } \\
\text { the task in the } \\
\text { workheet given. }\end{array}$ & $\begin{array}{l}\text { 1O. I' } m \text { going to } \\
\text { show you a vidio. }\end{array}$ & $\begin{array}{l}\text { Initiating }>\text { statement }>\text { to } \\
\text { inform }\end{array}$ & $\begin{array}{l}\text { Giving } \\
\text { information }\end{array}$ \\
\hline 7. & $\begin{array}{l}\text { Teacher: sure, what } \\
\text { do you want to ask } \\
\text { tina? }\end{array}$ & $\begin{array}{l}\text { 11. sure, what } d o \text { you } \\
\text { want to ask tina? }\end{array}$ & $\begin{array}{l}\text { Responding > responding } \\
\text { to statement > agree }\end{array}$ & $\begin{array}{l}\text { Asking } \\
\text { question }\end{array}$ \\
\hline 8. & $\begin{array}{l}\text { Student } 18: \text { it is } \\
\text { stated here, that we } \\
\text { use present perfect } \\
\text { tense when we are }\end{array}$ & $\begin{array}{l}\text { 12. it is stated here, } \\
\text { that we use present } \\
\text { perfect tense } \\
\text { 13. when we are }\end{array}$ & Initiating $>$ statement $>$ to & Giving \\
\hline
\end{tabular}




\begin{tabular}{|l|l|l|l|}
\cline { 2 - 3 } $\begin{array}{l}\text { considering } \\
\text { something that } \\
\text { started in the past }\end{array}$ & $\begin{array}{l}\text { opine } \\
\text { something that started } \\
\text { in the past and }\end{array}$ & & information \\
\end{tabular}




\begin{tabular}{|c|c|c|c|c|}
\hline & $\begin{array}{l}\text { and connect to the } \\
\text { present }\end{array}$ & connect to the present & & \\
\hline 9. & $\begin{array}{l}\text { Student } 19: \text { oh I } \\
\text { have been here for } \\
\text { quite a while }\end{array}$ & 14. I have been here & $\begin{array}{l}\text { Initiating }>\text { statement }>\text { to } \\
\text { opine }\end{array}$ & $\begin{array}{l}\text { Giving } \\
\text { information }\end{array}$ \\
\hline \multirow[t]{2}{*}{10.} & \multirow{2}{*}{$\begin{array}{l}\text { Teacher : ok class, } \\
\text { after you understand } \\
\text { the simple past and } \\
\text { present perpect. I'm } \\
\text { going to give you } \\
\text { another text. }\end{array}$} & $\begin{array}{lr}15 . \quad \text { after you } \\
\text { understand } & \begin{array}{r}\text { the } \\
\text { simple past and }\end{array} \\
\text { present perpect } & \end{array}$ & $\begin{array}{l}\text { Initiating }>\text { statement }>\text { to } \\
\text { inform }\end{array}$ & $\begin{array}{l}\text { Giving } \\
\text { information }\end{array}$ \\
\hline & & $\begin{array}{l}\text { 16. I'm going to give } \\
\text { you another text. }\end{array}$ & $\begin{array}{l}\text { Initiating }>\text { statement }>\text { to } \\
\text { inform }\end{array}$ & $\begin{array}{l}\text { Giving } \\
\text { information }\end{array}$ \\
\hline \multirow[t]{2}{*}{11.} & \multirow{2}{*}{$\begin{array}{l}\text { Student } 22: \text { I agree } \\
\text { with you, next host } \\
\text { elaborates the } \\
\text { question. Again } \\
\text { RidwanKamil } \\
\text { responds it. }\end{array}$} & 17. I agree with you & $\begin{array}{l}\text { Responding > responding } \\
\text { to statement > agree }\end{array}$ & $\begin{array}{l}\text { Giving } \\
\text { information }\end{array}$ \\
\hline & & $\begin{array}{l}\text { 18. next host } \\
\text { elaborates the } \\
\text { question. }\end{array}$ & $\begin{array}{l}\text { Responding > responding } \\
\text { to statement }> \\
\text { acknowledgee }\end{array}$ & $\begin{array}{l}\text { Giving } \\
\text { information }\end{array}$ \\
\hline \multirow[t]{2}{*}{12.} & \multirow{2}{*}{$\begin{array}{l}\text { Teacher : I am } \\
\text { happy to hear that, } \\
\text { don't worry, we still } \\
\text { have another } \\
\text { meeting to discuss } \\
\text { about it. }\end{array}$} & $\begin{array}{l}\text { 19. I am happy to } \\
\text { hear } \\
\text { 20. we still have }\end{array}$ & $\begin{array}{l}\text { Inititaion > statement }> \\
\text { to opine } \\
\text { Following up > }\end{array}$ & $\begin{array}{l}\text { Giving } \\
\text { information } \\
\text { Giving }\end{array}$ \\
\hline & & another meeting & complementary & information \\
\hline \multirow[t]{2}{*}{13.} & \multirow[t]{2}{*}{$\begin{array}{l}\text { Teacher: now let us } \\
\text { conclude what you } \\
\text { have learned today. }\end{array}$} & $\begin{array}{l}\text { 21. now let us } \\
\text { conclude } \\
\text { 22. what you have }\end{array}$ & $\begin{array}{l}\text { Initiating }>\text { request }> \\
\text { permission request } \\
\text { Initiating }>\text { request }>\end{array}$ & $\begin{array}{l}\text { Giving } \\
\text { order } \\
\text { Giving }\end{array}$ \\
\hline & & learned today. & permission request & order \\
\hline \multirow[t]{2}{*}{14.} & \multirow{2}{*}{$\begin{array}{l}\text { Teacher : we have } \\
\text { also learned, how } \\
\text { we ask and give } \\
\text { information about } \\
\text { experiences or past } \\
\text { events using past } \\
\text { simple or present } \\
\text { perpect. If we give } \\
\text { information about } \\
\text { an event which } \\
\text { finished at a } \\
\text { specific time in the } \\
\text { past, we use past }\end{array}$} & $\begin{array}{l}\text { 23. we have also } \\
\text { learned, }\end{array}$ & $\begin{array}{l}\text { Following up > } \\
\text { complementary }\end{array}$ & $\begin{array}{l}\text { Giving } \\
\text { information }\end{array}$ \\
\hline & & $\begin{array}{l}\text { 24. how we ask and } \\
\text { give information } \\
\text { about experiences or } \\
\text { past events using past } \\
\text { simple or present } \\
\text { perpect. } \\
25 \text { If we give } \\
\text { information about an } \\
\text { event which finished } \\
\text { at a specific time in }\end{array}$ & $\begin{array}{l}\text { Responding > responding } \\
\text { to statement }> \\
\text { acknowledge }\end{array}$ & $\begin{array}{l}\text { Giving } \\
\text { information }\end{array}$ \\
\hline
\end{tabular}

239 | IJET| Volume. 10, Issue 2. December 2021 Copyright 2021 Regina Marintan Silalahi, and Kammer Tuahman Sipayung are licensed under Creative Commons Atrribution-ShareAlike 4.0 International License. 
simple. When we want to stress the importance of a past event in the present, we use present perpect.

\begin{tabular}{|c|c|c|}
\hline the past & & \\
\hline $\begin{array}{l}\text { 26. we use past } \\
\text { simple. }\end{array}$ & $\begin{array}{l}\text { Initiating }>\text { statement }>\text { to } \\
\text { opine }\end{array}$ & $\begin{array}{l}\text { Giving } \\
\text { infomation }\end{array}$ \\
\hline $\begin{array}{l}27 . \text { When we want to } \\
\text { stress the importance }\end{array}$ & $\begin{array}{l}\text { Initiating }>\text { statement }>\text { to } \\
\text { inform }\end{array}$ & $\begin{array}{l}\text { Giving } \\
\text { infomation }\end{array}$ \\
\hline
\end{tabular}


ReginaSilalahi and KammertuahSipayung

\begin{tabular}{|l|l|l|l|l|}
\hline & & $\begin{array}{l}\text { of a past event in the } \\
\text { present, }\end{array}$ & & \\
\cline { 3 - 5 } & & $\begin{array}{l}\text { 28. We use present } \\
\text { perpect. }\end{array}$ & $\begin{array}{l}\text { Initiating > statement > to } \\
\text { inform }\end{array}$ & $\begin{array}{l}\text { Giving } \\
\text { infomation }\end{array}$ \\
\hline 15. & $\begin{array}{l}\text { thank you, you give } \\
\text { a good conclusion } \\
\text { Let's give applause. }\end{array}$ & \begin{tabular}{l} 
29. thank you, \\
\cline { 3 - 5 }
\end{tabular} & $\begin{array}{l}\text { Responding > responding } \\
\text { to statement > agree } \\
\text { conclusion }\end{array}$ & Closing \\
Responding > responding & Closing \\
to statement > agree & \\
\hline
\end{tabular}

Nb : Bold : Subject

: Italic Bold : Verb

30 : clauses

16 : minimal exchange structures

5 : general exchanges structures

\section{Verification}

The last step of data analysis is verifications. After making the data displayed in form of table then the researcher would be able to make conclusions/verifications. Based on the result before, exchange structures is sequence of communication that can be used to analyze the types of conversations. They develop a model exchange consisting of three parts : a questions, an answer, and a comment. The sequence of parts, each labelled as move, consists of initation (I) from the speaker, response (R) which is the speaker's comment on hearer, and follow up (F) which is the speaker's comment on hearer's answer. These moves are abbreviated to I-R-F and general exchange structures in english classroom interaction consists of : greeting, followed any kinds of functions such as, giving information, giving order, asking question, and closing. To make it clear, the researcher used table to know the result, as below: There are 30 clauses, 16 elements minimal exchange structures, and 5 general exchange structures. Anaylisis of minimal exchange structures and geeneral exchange stuctures with in found clause with the pattern are subject and verb, and find the minimal and general exchange structures can be illustrated in the following analysis.

Teacher : you are so happy and fresh today, I'm glad too see this. It mean you are all ready for English lesson. right?

Clauses : 1. you are so happy and fresh today

2. I'm glad to see this

3. It mean you are all ready for English

Pattern of clauses : subject + verb

Minimal : Initiating > statement $>$ to opine

General : Greetings

\section{Discussion}

After the data had been collected the conversation between teacher and students. Based on the data analysis, that it can be show the total of the clause analysis, there were 30 clauses, 16 element minimal exchange structures and 5 general exchange structures in the data. Identified in English Classroom interaction can be seen in below.

Language as the way to interaction need more practice, so that is the learning process of teaching and learning, students expected to more active than teacher. After conducting the research, the teacher was too dominant in talking than the students during the teaching and learning process. 


\section{CONCLUSION}

After analyzing the data, finding, discussing, conclusion are drawn as the followings :

Found word and clause with a pattern that is: subject + verb, which is contained in the conversation of students and teachers during the teaching and learning process in English classroom interaction found in youtube from mujikuy channel : asking and giving information about berbasis gaanre in X class. Then after finding the clause and determining the pattern then find the minimal and general exchange structures.

30 clauses, 5 elements of general exchange structures and 16 elements of minimal exchange structures found in conversations between teachers and students during the teaching and learning process in English classroom interaction found in youtube from mujikuy channel : asking and giving information about berbasis gaanre in $\mathrm{X}$ class.

\section{Suggestion}

In relation to the conclusion, suggestion were staged as following.

The students who learnt in linguistics and students who interested with this study should understand about minimal exchange structures and general exchange structures until this knowledge can be useful for students who wanted doing research deeper about collocations.

the teacher must be able to invite students to be more brave in interacting or speaking in the classroom, so that the classroom atmosphere becomes more lively and students are able to provide feedback when giving information to each other in the classroom.

\section{APPENDIX 1}

30 clause, 14 minimal exchange structures, and 5 general exchange structures. English classroom interaction

Teacher : good morning class !

Student : good morning. Ma'am.

Teacher : you are so happy and fresh today, im glad too see this. It mean you are all ready for english lesson, right?

\begin{tabular}{|c|c|c|c|c|}
\hline \multirow[t]{2}{*}{ NO } & \multirow{2}{*}{$\begin{array}{l}\text { English Classroom } \\
\text { Interaction }\end{array}$} & \multirow[t]{2}{*}{ Clause } & \multicolumn{2}{|l|}{ Exchange structures } \\
\hline & & & Minimal & General \\
\hline \multirow[t]{3}{*}{1.} & \multirow{3}{*}{$\begin{array}{l}\text { Teacher : you are so } \\
\text { happy and fresh } \\
\text { today, I'm glad too } \\
\text { see this. It mean } \\
\text { you are all ready for } \\
\text { English lesson. } \\
\text { right? }\end{array}$} & $\begin{array}{l}\text { 1. you are so happy } \\
\text { and fresh today } \\
\text { 2. I'm glad to see this }\end{array}$ & $\begin{array}{l}\text { Initiating }>\text { statement }>\text { to } \\
\text { opine } \\
\text { Initiating }>\text { statement }>\text { to }\end{array}$ & $\begin{array}{l}\text { Greetings } \\
\text { Giving }\end{array}$ \\
\hline & & & opine & information \\
\hline & & $\begin{array}{l}\text { 3. It mean you are } \\
\text { all ready for English }\end{array}$ & $\begin{array}{l}\text { Tnitiating > question > } \\
\text { polarity questin }\end{array}$ & $\begin{array}{l}\text { Asking } \\
\text { question }\end{array}$ \\
\hline
\end{tabular}

Student 1: you too mam,

All student : ready ma'am.

Teacher : chairman, please lead the pray.

\begin{tabular}{|l|l|l|l|l|}
\hline 2. & $\begin{array}{l}\text { Teacher : chairman, } \\
\text { please lead the pray. }\end{array}$ & $\begin{array}{l}\text { 4. chairman, please } \\
\text { lead the pray. }\end{array}$ & $\begin{array}{l}\text { Initiating }>\text { request } \\
\text { action request }\end{array}$ & $\begin{array}{l}\text { Giving } \\
\text { order }\end{array}$ \\
\hline
\end{tabular}

Chairman : attention please, lets begin our lesson by saying bismillah together.

All students : praying

Teacher: where are indra and diyah ? they haven't come yet or absent? 
Student 2 (tina ): they are outside ma'am they came late.

\begin{tabular}{|l|l|l|l|l|}
\hline 3. & $\begin{array}{l}\text { Student 2 (Tina): } \\
\text { they are outside } \\
\text { ma'am they came } \\
\text { late. }\end{array}$ & $\begin{array}{l}\text { Responding > responding } \\
\text { to statement>acknowledge }\end{array}$ & $\begin{array}{l}\text { Giving } \\
\text { information }\end{array}$ \\
\hline
\end{tabular}

Teacher : thank you tina for your information. I hope they will join us soon, so they won't miss the lesson. Well class, this morning $\mathrm{i}$ am going to show you a picture taken from last night news. So please pay attention to this.

Student 3 : when did it happen? I haven't heard about it, ma'am?

Student 4 (yiyin) : me too ma'am.

Teacher : you didn,t either yiyin?

Student 5 : i knew it ma'am. Because i went there last night

Teacher : did you go there alone? And how many times have you been there?

Student $5:$ i went there with my brother, it is about three times.

Teacher : that's good, it means you like reading right ?

\begin{tabular}{|l|l|l|l|}
\hline $\begin{array}{l}\text { Teacher: that's } \\
\text { good, it means you } \\
\text { like reading right? }\end{array}$ & 6. that's good & $\begin{array}{l}\text { Responding > responding } \\
\text { to statement > agree }\end{array}$ & $\begin{array}{l}\text { Giving } \\
\text { information }\end{array}$ \\
\cline { 2 - 4 } & $\begin{array}{l}\text { 7. means you like } \\
\text { reading right? }\end{array}$ & $\begin{array}{l}\text { Initiating > question > } \\
\text { confirmation question }\end{array}$ & $\begin{array}{l}\text { Asking } \\
\text { question }\end{array}$ \\
\hline
\end{tabular}

Student $5:$ yes i do

Teacher : i hope many of your friends in this class also love reading too. Well clas. Do you know why we have to learn about past event like what happened in this picture. Do you think it is important?

Student 6 (adam) : ma'am.

Teacher : yes

Student 6 (adam ) : for giving a news or just sharing experience. Important or not it depends to whom we talk and what for.

Student 7 (sari) : i agree with adam opinion ma'am. In daily live we ususally tell our experience to others.

\begin{tabular}{|c|c|c|c|c|}
\hline 5. & $\begin{array}{l}\text { Student } 7 \text { (sari) : i'm } \\
\text { agree with adam }\end{array}$ & 8.I'm agree & $\begin{array}{l}\text { Responding > responding } \\
\text { to statement }>\text { agree }\end{array}$ & $\begin{array}{l}\text { Giving } \\
\text { information }\end{array}$ \\
\hline & $\begin{array}{l}\text { daily live we tell ou } \\
r \text { experience to } \\
\text { others. }\end{array}$ & $\begin{array}{l}\text { 9. with adam opinion } \\
\text { ma'am. }\end{array}$ & $\begin{array}{l}\text { Responding > responding } \\
\text { to statement }>\text { agree }\end{array}$ & $\begin{array}{l}\text { Giving } \\
\text { information }\end{array}$ \\
\hline
\end{tabular}

Teacher : good idea adam sari, what both of you talk about is the right thing . thats why we have or are going to talk about. Past event and experiences in our leson today.

Well... the aim of our lesson today is to make you all be able to conduct an interaction. To ask and giving information dealing with past event . refers to the time of its occurence and ending. Our today agenda is groups activities such as watching vidio, discussion and role playing. To do all those activitiest you have to sit in groups of 4 . You may start right now.

*After do some groups *

Teacher : ok well class. I'm going to show you a vidio. And please watch the conversation and then repeat it and you have to do the task in the workheet given. 
$6 . \quad$ Teacher :ok well 10 . I'm going to

class. I'm going to show you a vidio.

Initiating > statement $>$ to Giving

244 | IJET| Volume. 10, Issue 2. December 2021

Copyright 2021 Regina Marintan Silalahi, and Kammer Tuahman Sipayung are licensed under Creative Commons Atrribution-Share Alike 4.0 International License. 


\begin{tabular}{|c|c|c|}
\hline $\begin{array}{l}\text { show you a vidio. } \\
\text { And please watch } \\
\text { the conversation } \\
\text { and then repeat it } \\
\text { and you have to do } \\
\text { the task in the } \\
\text { workheet given. }\end{array}$ & inform & information \\
\hline
\end{tabular}

Student 8 : Excusme ma'am.

Teacher : yes

Student $8:$ i need your help here.

Teacher: what is the problem?

Student 8 : how we do this assigment?

Teacher: well you have do discuss the answers but you don't need to write them because you are going to report orally, ok?

Students : thankyou very much ma'am

Teacher : you are welcome

Teacher : ok class any one wo answer of question number 1 ?

Student 9(irfan) : me ma'am

Teacher: ok irfan please

Student 9(irfan) : linda, ekky, and bagas were involved the dialogue.

Teacher : very good irfan, next who is going to answer the question number 2 ?

Student 10 : may i answer ma'am?

Teacher : sure

Student 10 : talking about proposal annual camping.

Teacher : any volunteer for number 3 ?

Student 11 ( linda) : adam and ekky.

Teacher : please rise your hand first linda,

Student 11 ( linda) : sorry ma'am.

Teacher: what is your answer?

Student 11 ( linda) : adam and ekky have been to the new place

Teacher : good answer linda

Student 12 ( tasya) : ma'am i would like to answer number 4

Teacher : go ahead

Student 12 (tasya) : they will discuss and review the proposal before giving it to the principal

Teacher : good thank you tasya

Gilang can you answer the question number 5 ?

Student 13 ( gilang) : hmm... sorry ma'am i don't know the answer

Student : ok any one can aswer number 5?

Student 13 (syifa) : may i try ma'am?

Teacher : ofcourse

Student 13 (syifa): i think what the sentence means that the proposal have already finished. Am i right, ma'am?

Teacher : you are right syifa. well class i'm so proud of you all the groups did good job. Thank you

Well, class i am going to show you a text. Please pay attention to this text. And the discuss in your group. If you dont understand please be free to ask.

Student 14 (tina) : ma'am may i ask you?

Teacher : sure, what do you want to ask tina?

245 | IJET| Volume. 10, Issue 2. December 2021

Copyright 2021 Regina Marintan Silalahi, and Kammer Tuahman Sipayung are licensed under Creative Commons Atrribution-ShareAlike 4.0 International License. 
Student 14 (tina) : what is the difference between present perfect and past simple, ma'am?

Teacher : good question. Is there anyone who want to answer tina's question?

Student 15 : may i try it ma'am?

Teacher : yah sure

Student 15 : to me the difference is in the form, look at the first sentence " $\mathrm{i}$ have just finished our peoposal" used have and verb 3. But in past simple no have.

Student 14 (tina) : may i say it in indonesia ma'am?

Teacher : sure

Student 14 (tina) : kalau have finish baru saja selesai sedangkan sudah lama terjadinnya.

Teacher : good job jonny and tina your answer almost perpect.

This is the website you can use your mobile to browse the addres and the after that please practice the conversation that given in the website.

Student 16 : look at this yen

Student 17 : what? Do you find something?

Student 16 : what jonny has said is correct

Student 17 : let me see.

Student 18 : it is stated here, that we use present perfect tense when we are considering something that started in the past and connect to the present

\begin{tabular}{|c|c|c|c|c|}
\hline \multirow[t]{2}{*}{8.} & \multirow{2}{*}{$\begin{array}{l}\text { Student } 18 \text { : it is } \\
\text { stated here, that we } \\
\text { use present perfect } \\
\text { tense when we are } \\
\text { considering } \\
\text { something that } \\
\text { started in the past } \\
\text { and connect to the } \\
\text { present }\end{array}$} & $\begin{array}{l}\text { 12. it is stated here, } \\
\text { that we use present } \\
\text { perfect tense } \\
\text { 13. when we are }\end{array}$ & Initiating $>$ statement $>$ to & Giving \\
\hline & & $\begin{array}{l}\text { considering } \\
\text { something that started } \\
\text { in the past and } \\
\text { connect to the present }\end{array}$ & opine & information \\
\hline
\end{tabular}

Student 19 : the screen is too small could you read it for us,

Student 17 : let me read it. It said in the affirmarive we often use the preposition for or since with a rime phrase and the adverb just and already .

Student 19 : lets practice the conversation

Student 20 : but there are only two people talking in the web

Student 14 (tina) : what if you both go first and we will go next

Student 21 : yeah let me hear you first

(Practice the conversation 1 group)

Student 14 (tina) : hello shella i did not expect tom see you here.

Student 19 : oh $\mathrm{i}$ have been here for quite a while

\begin{tabular}{|l|l|l|l|l|}
\hline 9. & $\begin{array}{l}\text { Student 19: oh I } \\
\text { have been here for } \\
\text { quite a while }\end{array}$ & 14. I have been here & $\begin{array}{l}\text { Initiating > statement > to } \\
\text { opine }\end{array}$ & $\begin{array}{l}\text { Giving } \\
\text { information }\end{array}$ \\
\hline
\end{tabular}

Student 14 (tina) : when you arrive

Student 19 : just after lunch

Student 14 (tina) : did patrick pick you up from the station?

Student 19 : no, it was a nice day so i walked.

Teacher : good!

Student 1 : now, lets try the dialogue, shall we?

247| IJET| Volume. 10, Issue 2. December 2021

Copyright 2021 Regina Marintan Silalahi, and Kammer Tuahman Sipayung are licensed under Creative Commons Atrribution-ShareAlike 4.0 International License. 
Practice the conversation..............

Teacher : ok good job!

248| IJET| Volume. 10, Issue 2. December 2021

Copyright 2021 Regina Marintan Silalahi, and Kammer Tuahman Sipayung are licensed under Creative Commons Atrribution-ShareAlike 4.0 International License. 
Students : thak you ma'am.

Teacher: you are welcome

Teacher : ok class, after you understand the simple past and present perpect. I'm going to give you another text . this one.

\begin{tabular}{|c|c|c|c|c|}
\hline \multirow{2}{*}{\multicolumn{2}{|c|}{\begin{tabular}{l|l}
10. & Teacher : ok class, \\
& after you understand \\
the simple past and \\
present perpect. I'm \\
going to give you \\
another text.
\end{tabular}}} & $\begin{array}{ll}15 . \quad \text { after you } \\
\text { understand } & \text { the } \\
\text { simple past and } \\
\text { present perpect }\end{array}$ & $\begin{array}{l}\text { Initiating }>\text { statement }>\text { to } \\
\text { inform }\end{array}$ & $\begin{array}{l}\text { Giving } \\
\text { information }\end{array}$ \\
\hline & & $\begin{array}{l}\text { 16. I' } m \text { going to give } \\
\text { you another text. }\end{array}$ & $\begin{array}{l}\text { Initiating }>\text { statement }>\text { to } \\
\text { inform }\end{array}$ & $\begin{array}{l}\text { Giving } \\
\text { information }\end{array}$ \\
\hline
\end{tabular}

Please analyze it by giving arrow loke what you have discussed in the first text.

*Sudents try to analyzed*

teacher : give arrow like that one, so decide the word is present perperct or simple past student talk to student

student 21 : lets start with this point, to me host initiates the conversation and is responded by ridwan kamil.

Student 22 : i agree with you, next host elaborates the question. Again ridwan kamil responds it

\begin{tabular}{|c|c|c|c|c|}
\hline \multirow{2}{*}{11.} & \multirow{2}{*}{$\begin{array}{l}\text { Student 22: I agree } \\
\text { with you, next host } \\
\text { elaborates the } \\
\text { question. Again } \\
\text { RidwanKamil } \\
\text { responds it. }\end{array}$} & 17. I agree with you & $\begin{array}{l}\text { Responding > responding } \\
\text { to statement }>\text { agree }\end{array}$ & $\begin{array}{l}\text { Giving } \\
\text { information }\end{array}$ \\
\hline & & $\begin{array}{l}\text { 18. next host } \\
\text { elaborates the } \\
\text { question. }\end{array}$ & $\begin{array}{l}\text { Responding > responding } \\
\text { to statement }> \\
\text { acknowledgee }\end{array}$ & $\begin{array}{l}\text { Giving } \\
\text { information }\end{array}$ \\
\hline
\end{tabular}

student 23 : both of you are right, now look at how ridwan kamil answered the questions from the host.

Student 24 : now look at how ridwan kamil answered the questions from the host .

Ridwan kamil answered using past simple and present perpect.

Student 25 : agree with your opinion santi. Ridwan kamil respond pakai keduanya.

Teacher : ok class, time is enough. Please attach your paper on the whiteboard. If you have any comment please write it at the given space.

Well class, all of the group did a good job . give applause for us, now im sure you all have this book right?

Students : yes ma'am

Teacher : so, now please open your book page 204 task 3 Ok everyone. Time to do the task is over. Please collect your book.

Teacher : Chairman, please help me to collect them all

Student 1 : ok ma'am.

Teacher : thankyou

Student 1 : yes ma'am

Teacher : an achievement game. Then this how to do it.

Teacher : got it?

249 | IJET| Volume. 10, Issue 2. December 2021

Copyright 2021 Regina Marintan Silalahi, and Kammer Tuahman Sipayung are licensed under Creative Commons Atrribution-ShareAlike 4.0 International License. 
Students : got it ma'am.

Teacher : ok good.

Student to student

Student 2 : have you ever acted in the play?

Student 3 : yes, i have.

Student 2 : when did you do that?

Student $3:$ i did that for the first time in 2012.

student 4 : have you ever eaten snake ?

Student 5 : yes i have.

student 4 : how was it is taste?

Student 5 : it was weird.

Teacher: okay good job

Teacher: i can see you no have problem in doing the game. That's a good job everyone.

Teacher : okay you may sitdown now. So, it is a fun game, is not it?

Students : it is fun ma'am.

Teacher : i am happy to hear that, don't worry, we still have another meeting to discuss about it.

\begin{tabular}{|c|c|c|c|c|}
\hline 12. & $\begin{array}{l}\text { Teacher : I am } \\
\text { happy to hear that, } \\
\text { don't worry, we still } \\
\text { have another }\end{array}$ & $\begin{array}{l}\text { 19. I am happy to } \\
\text { hear } \\
\text { 20. we still have }\end{array}$ & $\begin{array}{l}\text { Inititaion }>\text { statement }> \\
\text { to opine } \\
\text { Following up > }\end{array}$ & $\begin{array}{l}\text { Giving } \\
\text { information } \\
\text { Giving }\end{array}$ \\
\hline & $\begin{array}{l}\text { meeting to discuss } \\
\text { about it. }\end{array}$ & another meeting & complementary & information \\
\hline
\end{tabular}

Teacher : Now let us conclude what you have learned today.

\begin{tabular}{|l|l|l|l|l|l|}
\hline 13. & $\begin{array}{l}\text { Teacher : now let us } \\
\text { conclude what you } \\
\text { have learned today. }\end{array}$ & $\begin{array}{l}\text { 21. now let us } \\
\text { conclude } \\
\text { 22. what you have }\end{array}$ & $\begin{array}{l}\text { Initiating > request > } \\
\text { permission request } \\
\text { Initiating > request > }\end{array}$ & $\begin{array}{l}\text { Giving } \\
\text { order }\end{array}$ \\
\cline { 3 - 6 } & learned today. & permission request & order \\
\hline
\end{tabular}

Student 8 : may i add it, ma'am?

Teacher : sure

Student 8 : we have also learned, how we ask and give information about experiences or past events using past simple or present perpect. If we give information about an event which finished at a specific time in the past, we use past simple. When we want to stress the importance of a past event in the present, we use present perpect.

\begin{tabular}{|l|l|l|l|l|}
\hline 14. & $\begin{array}{l}\text { Teacher : we have } \\
\text { also learned, how } \\
\text { we ask and give }\end{array}$ & $\begin{array}{l}\text { 23. we have also } \\
\text { learned, }\end{array}$ & $\begin{array}{l}\text { Following up > } \\
\text { complementary }\end{array}$ & $\begin{array}{l}\text { Giving } \\
\text { information }\end{array}$ \\
\hline
\end{tabular}




\begin{tabular}{|c|c|c|c|}
\hline $\begin{array}{l}\text { information about } \\
\text { experiences or past } \\
\text { events using past } \\
\text { simple or present } \\
\text { perpect. If we give } \\
\text { information about } \\
\text { an event which } \\
\text { finished at a } \\
\text { specific time in the } \\
\text { past, we use past }\end{array}$ & $\begin{array}{l}\text { 24. how we ask and } \\
\text { give information } \\
\text { about experiences or } \\
\text { past events using past } \\
\text { simple or present } \\
\text { perpect. } \\
\text { 25. If we give } \\
\text { information about an } \\
\text { event which finished }\end{array}$ & $\begin{array}{l}\text { Responding > responding } \\
\text { to statement }> \\
\text { acknowledge }\end{array}$ & $\begin{array}{l}\text { Giving } \\
\text { information }\end{array}$ \\
\hline \multirow[t]{2}{*}{$\begin{array}{l}\text { simple. When we } \\
\text { want to stress the } \\
\text { importance of a past } \\
\text { event in the present, } \\
\text { we use present } \\
\text { perpect. }\end{array}$} & $\begin{array}{l}\text { at a specific time in } \\
\text { the past } \\
26 \text {. we use past } \\
\text { simple. } \\
27 . \text { When we want to } \\
\text { stress the importance } \\
\text { of a past event in the } \\
\text { present, }\end{array}$ & $\begin{array}{l}\text { Initiating }>\text { statement }>\text { to } \\
\text { opine } \\
\text { Initiating }>\text { statement }>\text { to } \\
\text { inform }\end{array}$ & $\begin{array}{l}\text { Giving } \\
\text { infomation } \\
\text { Giving } \\
\text { infomation }\end{array}$ \\
\hline & $\begin{array}{l}\text { 28. We use present } \\
\text { perpect. }\end{array}$ & $\begin{array}{l}\text { Initiating }>\text { statement }>\text { to } \\
\text { inform }\end{array}$ & $\begin{array}{l}\text { Giving } \\
\text { infomation }\end{array}$ \\
\hline
\end{tabular}

Teacher : thank you, you give a good concluion. Let's give applause.

\begin{tabular}{|c|c|c|c|c|}
\hline \multirow{2}{*}{15.} & \multirow{2}{*}{$\begin{array}{l}\text { thank you, you give } \\
\text { a good conclusion } \\
\text { Let's give applause. }\end{array}$} & 29. thank you, & $\begin{array}{l}\text { Responding }>\text { responding } \\
\text { to statement }>\text { agree }\end{array}$ & Closing \\
\hline & & $\begin{array}{l}\text { 30. you give a good } \\
\text { conclusion }\end{array}$ & $\begin{array}{l}\text { Responding }>\text { responding } \\
\text { to statement }>\text { agree }\end{array}$ & Closing \\
\hline
\end{tabular}

Teacher : for homework, please practice asking and giving information about experiences with your friends and record it using your cellular, after that please send it to me through LINE, WA, or Email. And the last information is about our agenda for next meeting. That we are going to practice more about this competency through talk show and chat.

Teacher: what are we going to do class?

Students : we are going to perform a talk show, yes.. tes...yes...

Teacher : very good

Teacher: what are we going to do class?

Students : we are going to have a chat..yes...yes..yes..

Teaher : thank you very much. I will see you next week.

\section{Appendix 2}


ReginaSilalahi and KammertuahSipayung

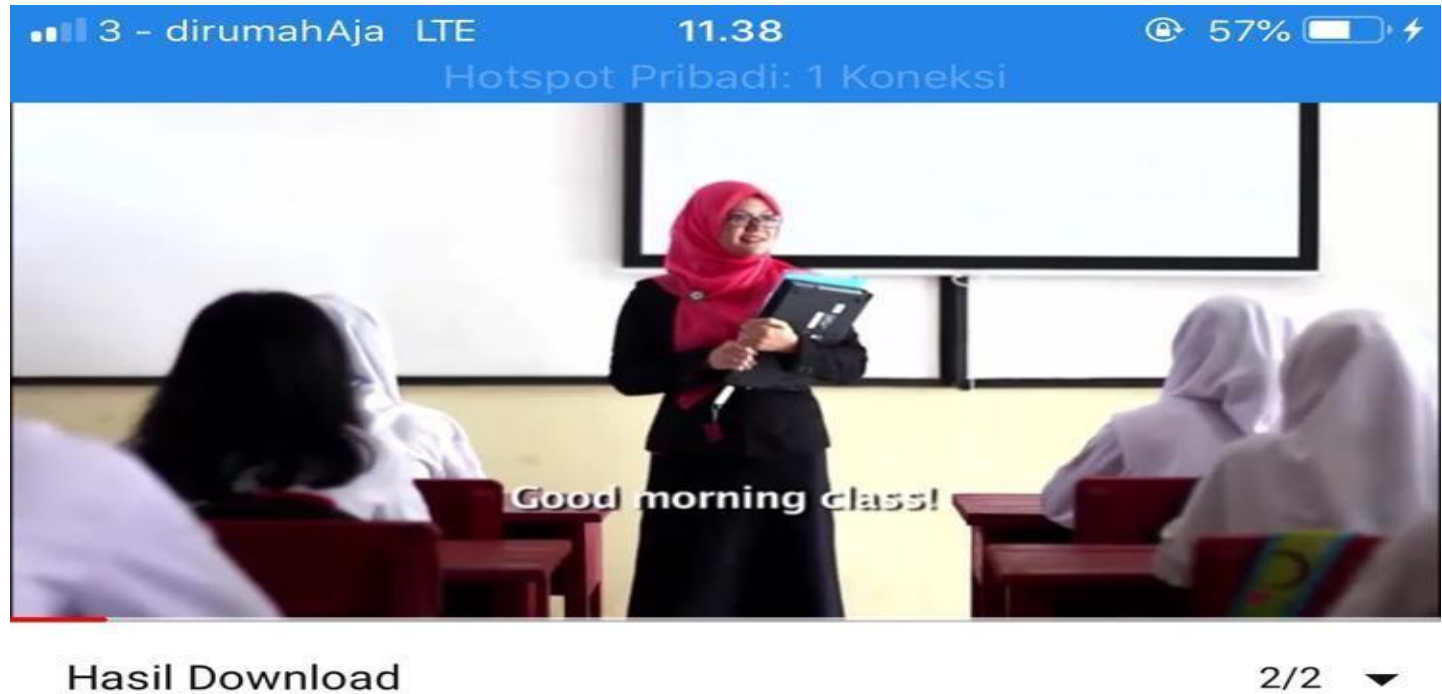

K13 Cara Belajar Mengajar Bahasa Inggris di Kelas 2017

$108.950 \times$ ditonton 3 tahun lalu

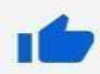

725

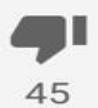

45

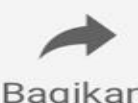

Bagikan

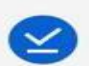

Didownload

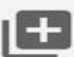

Simpan

\section{Mojikuy}

626 subscriber

\section{DISUBSCRIBE}

Dipublikasikan tanggal 23 Jul 2017

BIMTEK 2017 KURIKULUM 2013 REVISI (CONTOH VIDEO

PEMBELAJARAN B. ING )

https://youtu.be/4figC69uA2I

252 | IJET| Volume. 10, Issue 2. December 2021

Copyright 2021 Regina Marintan Silalahi, and Kammer Tuahman Sipayung are licensed under Creative Commons Atrribution-ShareAlike 4.0 International License. 


\section{REFFERENCES}

Alaei, M. 2016. A Study of Ideational Metafunction in Joseph Conrad"s "Heart of ": A Critical Discourse Analysis. Canada: Canadian Center of Science and Education.

Ary, D, Lucy \& Chris. 2010. Introduction to Research in Education. Canada: Wadsworth, Cengage Learning

Brown. H. 2010. Exchange Structure in the Modern Classroom:,Jamie"s Dream School". The University of Nottingham.

Creswell. 2014. Research Design : Qualitative, Quantitative, and Mixed Methods Approaches (3rd edition). New Jersey: Pearson Education International.

Derry. S. J.2007. Guides For Vidio Research In Education. Chicago : National Science Fundation (NSF)

Gerot, L. and P. Wignel. 1994. Making Sense of Functional Grammar. Sydney: Tanya Stabler.

Ginting, S. A. 2010. Sistem dan Struktur Percakapan Dalam Bahasa

Karo. Disertasi. Medan: USU

Ginting, S. A. 2015. Structure of Karonese Conversation in the Funeral:

Case Study in Indonesia. Journal Asian Social Science. Canadian

Center of Science and Education Vol. 11, No. 13.

Halliday, M.A.K. 1994. Text as Semantic Chise in Social Context. London: Oxford University Press.

Halliday, M.A.K. 2004. An Introduction to Functional Grammar 3rd. Australia: University of Sydney.

Rafsanjani. R. F.and Mirahayani.N.K. (2018). Classroom Communicative Structure: Exchange Structure in EFL Class in Public Senior High School 3 Mojokerto. Anaphora : journal of language, literary, and cultural studies vol. 1. No.1 p.9-11

Saragih, Amrin. 2004. Introducing Functional Grammar. Medan: UNIMED.

Saragih, Amrin. 2014. Discourse Analysis: A Study on Discourse Based on Systemic Functional Linguistic Theory. Medan: UNIMED.

Shalehodin. 2016. "Move" Analysis in Classroom Interaction'. Journal Anglo- Saxon. University of Riau Kepulauan, Batam, Indonesia. Vol.7 No.1.

Sipayung, T.K. and Pangaribuan T.(2019). Developing Teaching Materials on English Specific Purposes on Tourism Program of HKBP Grade Eleven. Asian EFL Journal Research Articles, 23(6):95

Sipayung, T.K. (2016). Metafunction Realization on Students' descriptive paragraph . international journal of linguistics. P.23

253 | IJET| Volume. 10, Issue 2. December 2021

Copyright 2021 Regina Marintan Silalahi, and Kammer Tuahman Sipayung are licensed under Creative Commons Atrribution-ShareAlike 4.0 International License. 
Sitorus, N., \& Silitonga, H. (2018). THE IMPLEMENTATION OF DIRECT METHOD TO IMPROVE STUDENTS'ABILITY IN SPEAKING. ELTIN JOURNAL, Journal of English Language Teaching in Indonesia, 6(2), 79-84.

Sunardi. 2016. "English Curriculum Genre: Pedagogic Negotiation Patterns in the IndonesianEFL Classroom. International Journal Linguistics. Vol. 8, No.6.

Walsh, S. 2011. Exploring classroom discourse: Language in action. London: Routledge.

Yu, W. 2009. An Analysis of College English Classroom Discourse. Qingdao: Qingdao University of Science and Technology.

https://www.oxfordlearnersdictionaries.com.16:58 PM

https://papers.ssrn.com/sol3/papers.cfm?abstract_id=2768579\&download=yes 